\title{
A UNIFIED TREATMENT OF HILBERT-TYPE INEQUALITIES INVOLVING THE HARDY OPERATOR
}

\author{
TSERENDORJ BATBOLD AND YOSHIHIRO SAWANO
}

Abstract. In this paper we shall provide a unified treatment of Hilbert-type inequalities involving the Hardy operator with a general homogeneous kernel. Furthermore, we establish some new Hilbert-type inequalities involving the integral operator. We shall show that the constants in our results are best possible.

Mathematics subject classification (2010): Primary 26D10, 26D15; Secondary 33B15.

Keywords and phrases: Hilbert's inequality, Hardy's inequality, the best possible constant, homogeneous function.

\section{REFERENCES}

[1] V. Adiyasuren, Ts. Batbold, Some new inequalities of Hardy-Hilbert type, Mongolian Math. J. 15, 12-19 (2011)

[2] V. Adiyasuren, Ts. BAtBold, Some new inequalities similar to Hilbert-type integral inequality with a homogeneous kernel, J. Math. Inequal. 6 (2012), 183-193.

[3] V. Adiyasuren, Ts. Batbold, New multiple inequality similar to Hardy-Hilbert's integral inequality, Tamsui Oxf. J. Inf. Math. Sci. 28 (2012), 281-292.

[4] V. AdiyASUREn, Ts. BATBOLD, M. KRniĆ, Hilbert-type inequalities including some operators, the best possible constants and applications: a survey, in "Topics in Mathematical Analysis and Applications", L. Toth and Th. M. Rassias, Eds., Springer, 2014, pp. 17-52.

[5] I. BRnetić, M. KRnić, J. PeČARIĆ, Multiple Hilbert and Hardy-Hilbert inequalities with nonconjugate parameters, Bull. Austral. Math. Soc. 71 (2005), 447-457.

[6] N. Das, S. SAhoo, New inequalities similar to Hardy-Hilbert's inequality, Turk. J. Math. 34 (2010), $153-165$.

[7] G. D. HandLey, Hilbert and Hardy type inequalities, thesis, The University of Melbourne, 2006.

[8] G. H. Hardy, J. E. Littlewood, G. Polya, Inequalities, Cambridge University Press Cambridge, 1952.

[9] M. KRNIĆ, On the multidimensional Hilbert-type inequalities involving the Hardy operator, Filomat 26:4 (2012), 845-857.

[10] M. Krnić, J. PeČArić, I. Perić, P. Vuković, Recent Advances in Hilbert-type Inequalities, Element, Zagreb, 2012.

[11] A. Kufner, L. Maligranda, L. E. Persson, The Hardy inequality - About its history and some related results, Vydavatelský servis, Pilsen, 2007.

[12] X. LiU, B. YAng, On a new Hilbert-Hardy-type integral operator and applications, J. Inequal. Appl. 2010 (Article ID 812636), 10 pp, 2010.

[13] D. S. Mitrinovic, J. E. PeCARIC, A. M. FinK, Classical and new inequalities in analysis, Kluwer Academic Publishers, Dordrecht/Boston/London, 1993.

[14] A. R. Moazzen, R. LAShKaripour, Some new extensions of Hardy's inequality, Int. J. Nonlinear Anal. Appl. 5 (1) (2014), 98-109.

[15] I. Perić, P. Vuković, Multiple Hilbert's type inequalities with a homogeneous kernel, Banach J. Math. Anal. 5 (2011), 33-43.

[16] P. Vuković, Note on Hilbert-type inequalities, Turk. J. Math. 36 (2012), 253-262. 
[17] B. YANG, I. BRnEtić, M. KRniĆ, J. PEČARIĆ, Generalization of Hilbert and Hardy-Hilbert integral inequalities, Math. Inequal. Appl. 8 (2005), 259-272.

[18] B. YANG, T. M. RASSIAS, On a Hilbert-type integral inequality in the subinterval and its operator expression, Banach J. Math. Anal. 4 (2010), 100-110. 